\title{
Adjusting Sowing Dates Improved Potato Adaptation to Climate Change in Semiarid Region, China
}

\author{
Qi Hu ${ }^{1,2}$, Ning Yang ${ }^{3}$, Feifei Pan ${ }^{2, *}$, Xuebiao Pan ${ }^{1, *}$, Xiaoxiao Wang ${ }^{1}$ and Pengyu Yang ${ }^{1}$ \\ 1 College of Resources and Environmental Sciences, China Agricultural University, Beijing 100193, China; \\ s10020292@cau.edu.cn (Q.H.); wangxiaoxiao0902@126.com (X.W.); yangpy@163.com (P.Y.) \\ 2 Department of Geography, University of North Texas, Denton, TX 76203, USA \\ 3 Huairou District Branch, Beijing Meteorological Bureau, Beijing 101400,CChina; yangning_2017@163.com \\ * Correspondence: feifei.pan@unt.edu or fpan@unt.edu (F.P.); panxb@cau.edu.cn (X.P.); \\ Tel.: +86-10-6273-3506 (X.P.)
}

Academic Editor: Ross M. Welch

Received: 3 March 2017; Accepted: 13 April 2017; Published: 17 April 2017

\begin{abstract}
Yields of rainfed potato (Solanum tuberosum L.) in China's semiarid region are restricted by limited precipitation. Climate change could cause significant fluctuation in the rain-fed agricultural production due to the spatiotemporal changes in temperature and precipitation. As adjusting sowing dates proved to be an important management technique for improving grain yields, we examined how potato production can be improved by altering planting date in China's semiarid region, thus improving potato adaptation to climate change. Field trials with five target sowing dates (from late April to early June) were carried out in Inner Mongolia, China during four growing seasons (2010-2013), and the effects of sowing dates on potato development, yield and water use efficiency (WUE) were estimated. Results showed that although delayed sowing shortened the duration of potato growth period, non-significant thermal time differences after flowering stage was found among the treatments. However, greater precipitation was shown in three intermediate treatments. Potato yield was significantly affected by sowing dates, and intermediate sowing dates showed greater yield compared to the earlier or later sowing dates. Delayed sowing dates significantly improved WUE in a drier year. As for a normal year, earlier sowing dates promoted WUE because of less water consumption, but these increases came at the cost of reducing yields. Under the current climate conditions in the study area, the flexible sowing time for potato was determined as from early May to early June, and optimum sowing time was between 10 May and 27 May. In conclusion, adjusting sowing date affected duration, thermal time, and precipitation over potato growth period, and the optimal sowing date exhibited higher yield by obtaining greater precipitation, which could improve potato adaption to climate change.
\end{abstract}

Keywords: China's semiarid region; sowing date; potato; yield; thermal time

\section{Introduction}

Currently, climate change is occurring, marked by global warming with earth's temperature increasing by approximately $0.72{ }^{\circ} \mathrm{C}$ over the past 60 years. Climate warming is expected to affect global precipitation, evaporation, and evapotranspiration [1], and thus influence the amount and distribution of water resources [2]. However, the changes in the precipitation and evapotranspiration regime are proving to be neither spatially nor temporally uniform [3]. Wentsz et al. [4] have shown that wet regions would become wetter and dry regions would become drier. Qin et al. [5] and Wang et al. [6] established that the drought in China's semiarid regions has also shown an aggravated trend. Lobell et al. [7], Ahmed et al. [8], and Grenz et al. [9] showed these changes in heat and water 
resources could significantly affect crop development due to the increased thermal time, prolonged frost-free days, and water deficiency.

Potato, as an integral part of the world's food supply and industrial materials [10], is widely planted around the world due to its high productivity and strong adaptability. China has the largest potato planting area, accounting for $20-25 \%$ of the world's total potato cultivation area. Inner Mongolia, located in China's semiarid area, is one traditional and dominant potato producing region and provides almost one seventh of the China's total potato yield. However, the potato yield per unit area in Inner Mongolia is lower than the national average due to the limited precipitation and frequent occurrence of droughts, as reported by Hou et al. [11] and Wu et al. [12]. Additionally, You and Shen [13] found a significant climate warming trend in Inner Mongolia, which could cause fluctuation in the rain-fed agricultural production [14].

Tavakkoli and Oweis [15], Bange et al. [16] have shown that adjusting sowing dates is an important management technique for improving grain yields. Bassu et al. [17], Turner [18] explained that sowing dates could help to have the crop growing period coincide with the concentration of precipitation, improve water-use efficiency, and offer an escape from frost risk. The experiments of sowing dates have been carried out for various plants including wheat (Triticum aestivum L.) by Spink et al. [19], Yang et al. [20], and Conry [21], maize (Zea mays L.) by Cirilo and Andrade [22], Otegui et al. [23], and sunflower (Helianthus annuus L.) by Barros et al. [24], etc. These studies mainly considered the effects of sowing dates on the thermal time and reported that a delay of the sowing date significantly reduced grain yield due to the decreases in the amount of heat accumulated during the growing season.

However, the impact of sowing dates on the amount of rainfall obtained during the growing season has not been fully studied, and few studies linked the sowing date to climate change, particularly in the northern semiarid region in Inner Mongolia, China. Therefore, we wonder if potato adaptation can also be improved to avoid the negative impact of climate change by adjusting sowing dates in China's semiarid region. The objectives of this study were (1) to obtain the detailed plant growth characteristics (including leaf area index, dry biomass, and yield) in several sowing dates; (2) to make clear the changes in thermal time and precipitation during different growth stages causing by adjusting sowing dates; and (3) determine the flexible and optimal sowing date for potato based on the long-term climate records in the study area. Additionally, the impacts of climate change during the past 50 years on the potato sowing date were discussed.

\section{Methods and Materials}

\subsection{Study Area}

This study was conducted in the experimental fields at the Scientific and Observing Experimental Station of Agro-environment (SOESA) $\left(41^{\circ} 06^{\prime} \mathrm{N}, 111^{\circ} 28^{\prime} \mathrm{E}\right)$ in Wuchuan county, Inner Mongolia during 2010-2013 (Figure 1).

Wuchuan County has a typical continental climate characteristic, i.e., dry summer with abundant solar radiation, short frost-free period, as well as cold and windy winter. The annual precipitation is about $340 \mathrm{~mm}$ and $85.5 \%$ of the rainfall occurs between May and September. Daily temperature and accumulated precipitation during potato growing season in 2010-2013 is presented in Figure 2.

Because of a severe dry growing season in 2010 with total precipitation in May and June only $20.5 \mathrm{~mm}$, three supplemental irrigations were applied, i.e., $42.4 \mathrm{~mm}$ on 1 June, $38.2 \mathrm{~mm}$ on 28 June, and $42.4 \mathrm{~mm}$ on 26 July. No supplemental irrigation was done in the last three years, because 2011 was a normal year, 2012 and 2013 were relatively wet years. 


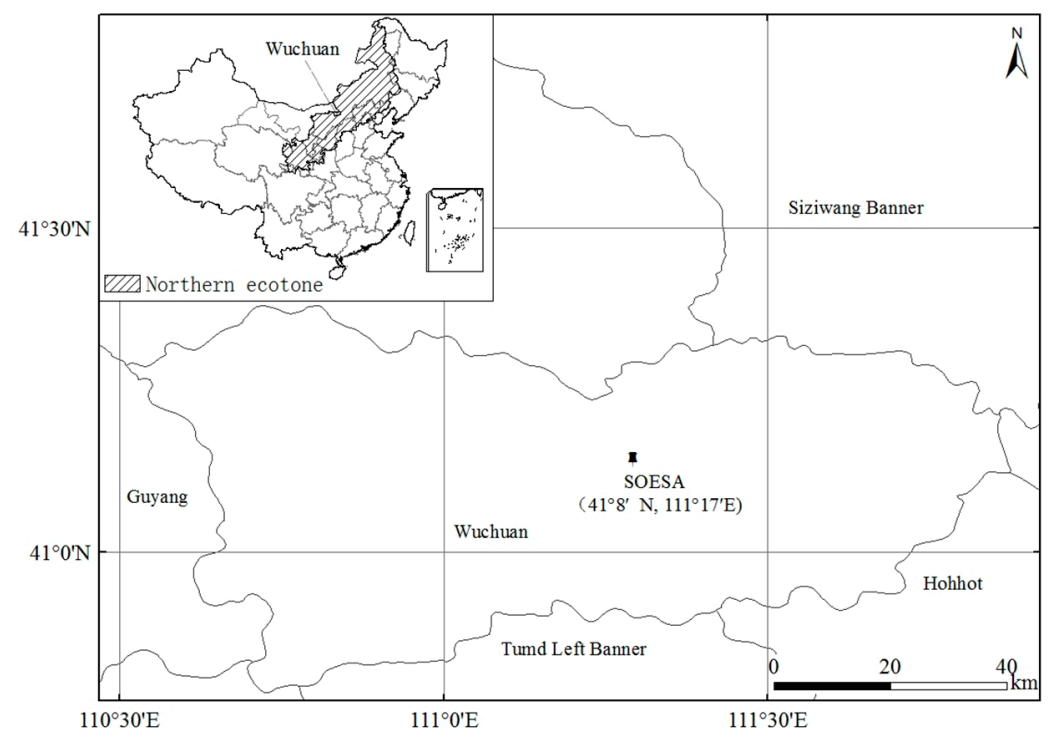

Figure 1. Map showing the location of the study area in Inner Mongolia, China.
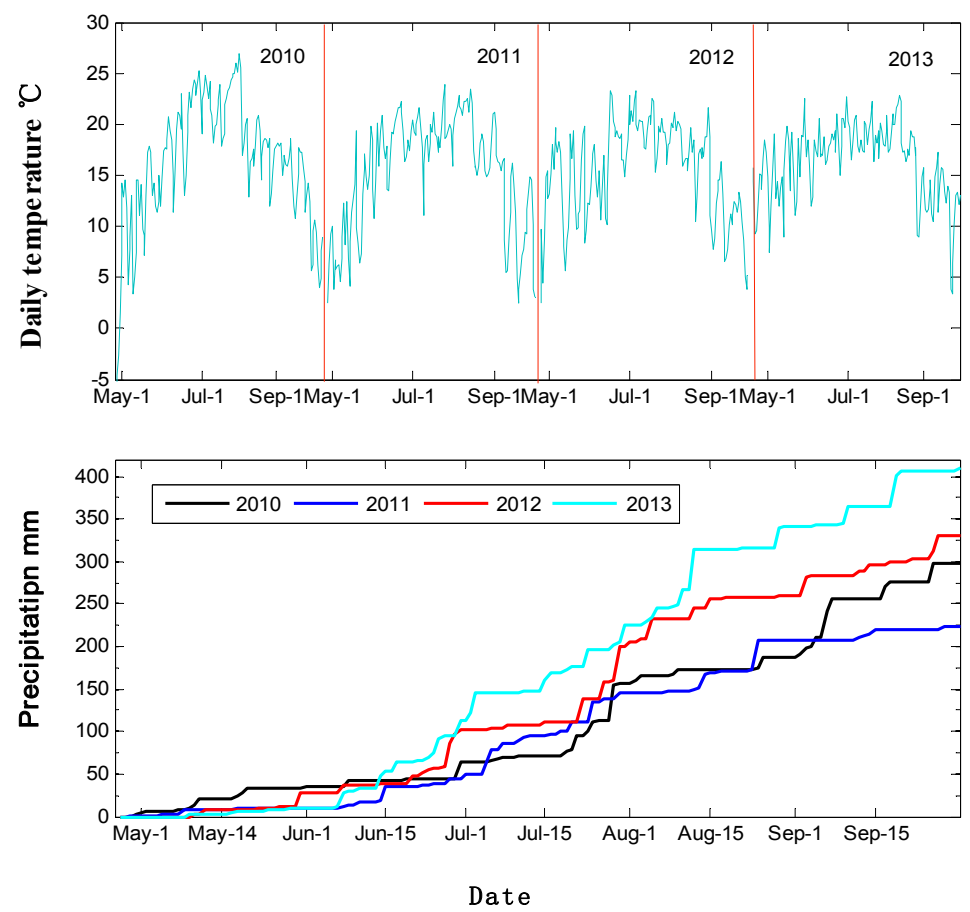

Figure 2. Daily temperature and accumulated precipitation during potato growing season in 2010-2013.

\subsection{Experimental Design}

Potato was sown on five different dates (D1-D5) from late April to early June with an about 10-day interval. The detailed sowing and harvesting dates in the different years are shown in Table 1.

The experimental design was a fully randomized block with four complete replications, and the five sowing dates were randomly distributed in each of the five blocks. The size of each plot was $5 \mathrm{~m} \times 5 \mathrm{~m}$ with 10 rows. The row spacing was $0.5 \mathrm{~m}$ and the distance between plants in each row was also $0.5 \mathrm{~m}$, providing a sowing density of 40,000 plants $/$ ha.

As all experiments were conducted in a single field with an area of 0.1 ha, soil physical and chemical properties were assumed to be spatially uniform. The soil type in the study area is Kastanozems with $\mathrm{pH}$ values ranging from 8.24 to 8.27 according to the World Reference Base for Soil Resources [20]. 
In the top 30-cm soil layer, the contents of total nitrogen, available phosphorus, available potassium, and organic matter are $1.09 \mathrm{~g} / \mathrm{kg}, 4.96 \mathrm{mg} / \mathrm{kg}, 105.27 \mathrm{mg} / \mathrm{kg}$, and $1.34 \%$, respectively. Basal fertilizers were incorporated into the top $15 \mathrm{~cm}$ of soil layer before sowing with urea ( $\mathrm{N}$ content $46.3 \%$ ) $90 \mathrm{~kg} / \mathrm{ha}$, ammonium dihydrogen phosphate ( $\mathrm{N}$ content $18 \%, \mathrm{P}_{2} \mathrm{O}_{5}$ content $46 \%$ ) $75 \mathrm{~kg} / \mathrm{ha}$, and potassium chloride $\left(\mathrm{K}_{2} \mathrm{O}\right.$ content $\left.60 \%\right) 60 \mathrm{~kg} / \mathrm{ha}$, and no extra fertilizer was applied during the potato growth period. Potato was sown and harvest manually, and weed control was performed by hand weeding throughout the growing season.

Table 1. Sowing date and harvesting date in the different years.

\begin{tabular}{cccccccc}
\hline Years & Treatments & Sowing Date & Harvesting Date & Years & Treatments & Sowing Date & Harvesting Date \\
\hline \multirow{2}{*}{2010} & D1 & 28 April & 27 August & 2012 & D1 & 26 April & 26 August \\
& D2 & 8 May & 8 September & & D2 & 6 May & 10 September \\
& D3 & 18 May & 10 September & & D3 & 16 May & 10 September \\
& D4 & 28 May & 16 September & & D4 & 26 May & 10 September \\
& D5 & 8 June & 20 September & & D5 May & 10 September \\
\hline \multirow{2}{*}{2011} & D1 & 26 April & 22 August & 2013 & D1 & 26 April & 25 September \\
& D2 May & 2 September & & D2 & 6 May & 25 September \\
& D3 & 16 May & 4 September & & D3 & 16 May & 25 September \\
& D4 & 26 May & 8 September & D4 May & 25 September \\
& D5 J June & 9 September & D5 & 31 May & 25 September \\
\hline \multicolumn{7}{c}{ Note: Potato was harvested when all the plants over ground withered. }
\end{tabular}

\subsection{Data Analyses}

The dates of potato growing stages for the five treatments were recorded, i.e., sowing date $(S D)$, seeding emergence stage (SE), flowering stage $(F L)$, and maturity stage $(M A)$. Three adjacent plants were taken as sampled plants at a sampling interval of 15 days shortly after seeding emergence in each plot, and the leaf area of each sampled plant was measured using a Portable Area Meter (Model: LI-3000C, LI-COR, Nebraska, NE, USA) immediately after sampling. The leaf area index (LAI) of a single plant is calculated as follows:

$$
L A I=\frac{\text { leaf area }\left(\mathrm{m}^{2} / \text { plant }\right)}{\text { plant projected ground area }\left(\mathrm{m}^{2}\right)}
$$

Biomass (including both above-ground and below-ground biomass) was then measured by the oven drying method $\left(105^{\circ} \mathrm{C}\right.$ for $30 \mathrm{~min}$, then $80^{\circ} \mathrm{C}$ for $8 \mathrm{~h}$ ) and expressed as dry-matter mass per plant ( $\mathrm{g} /$ plant) in each plot. Harvest was performed when all leaves became dry, and started from D1 to D5.

Gravimetric soil water contents in $0 \sim 100 \mathrm{~cm}$ soil column at $10 \mathrm{~cm}$ interval in each plot were measured using the oven-dried method $\left(105^{\circ} \mathrm{C}, 12 \mathrm{~h}\right)$. The total soil water storage (SWS) was calculated in each plot as follows:

$$
S W S=\sum_{i=1}^{n}\left(0.1 \rho \theta_{i} h_{i}\right)
$$

where $\rho$ is the soil bulk density $\left(\mathrm{g} \mathrm{cm}^{-3}\right), \theta_{i}$ and $h_{i}$ are the gravimetric soil water content $(\mathrm{g} / \mathrm{g} \%)$, and soil layer thickness $(\mathrm{cm})$ in soil layer $i$, respectively.

Yield was determined by harvesting potatoes in two 5-m row sections in the center of each plot. Potatoes were weighed and marketable yield was determined as the total weight of tubers with greater than $100 \mathrm{~g}$ weight. Both total yield and marketable yield values were expressed as ton/ha.

Water use efficiency (WUE, $\mathrm{kg}(\mathrm{mm} \mathrm{ha})^{-1}$ ) was the ratio of total yield per unit area $(Y)$ to water consumption during the growing season (ET) and given by Hu et al. [25].

$$
W U E=Y / E T
$$

ET was calculated according to soil water balance formula:

$$
E T=P+I+\Delta W-R-D
$$


where $P$ is precipitation during the potato growth period, $I$ is irrigation, $\Delta W$ is the difference in $0-100 \mathrm{~cm}$ soil moisture between sowing and harvesting time, $R$ is runoff, no runoff in the experiment plot, and $D$ is soil water infiltration (not considered here, $=0$ ).

\subsection{Statistical Analyses}

Since each treatment had four replications, and the yield data were repeatedly from the experimental units, thus, a single-factor analysis of variance with repeated observations in a randomized block design was conducted on the total yield and marketable yield using the analysis of variance (ANOVA; SAS Institute, 2008). Thermal time (unit ${ }^{\circ} \mathrm{C}$ day), which is the accumulated temperature over $0{ }^{\circ} \mathrm{C}$ during a period, was calculated in this study. A series of regression analyses between thermal time and plant performances (LAI, dry biomass, yield) were performed.

\section{Results}

\subsection{Precipitation and Duration (in Days and Thermal Time) at Different Potato Growth Stages}

The averaged data (from 2010 to 2012) for precipitation and duration (in days and thermal time) of different potato developmental phases in five trials (D1-D5) are shown in Figure 3.

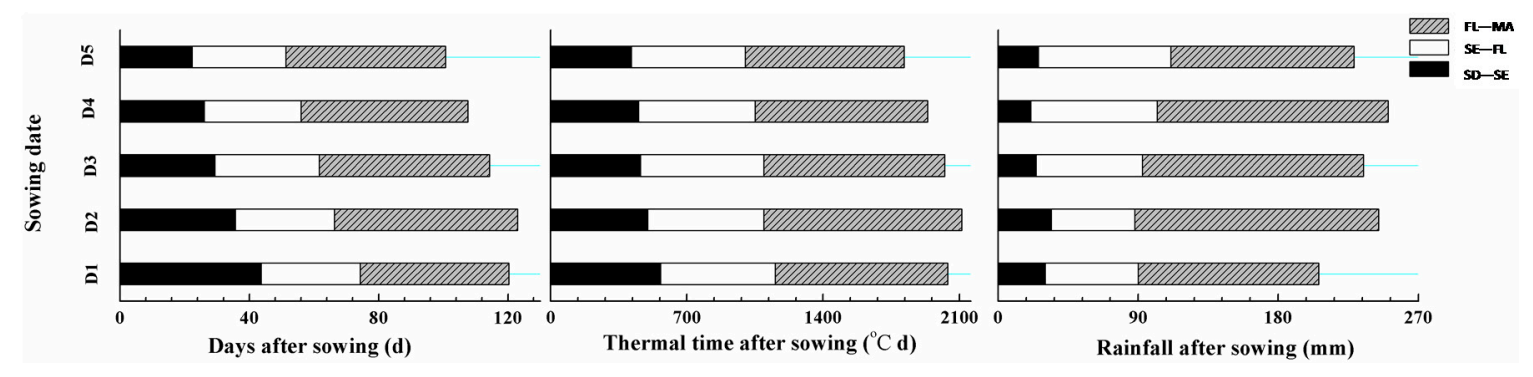

Figure 3. Precipitation, duration (in days and thermal time) of different developmental phases for potato in five different sowing dates. Phases are: sowing date $(S D)$, seeding emergence $(S E)$, SE-flowering $(F L)$, FL-maturity $(M A)$. D1-D5 labeled the five different sowing dates. Results are averaged from the data in 2010, 2011 and 2012.

The growth period, thermal time, and rainfall for the entire potato growing season were about 115 days, $1900{ }^{\circ} \mathrm{C}$ day, and $235 \mathrm{~mm}$ in the study area, respectively. Significant differences among the five treatments in the plant growth period and thermal time was shown from $S D$ to $S E$, as the sowing date delayed, both the growth period and thermal time from $S D$ to $S E$ decreased, i.e., potatoes for the first sowing date (D1) needed more days to emerge than other treatments. The range of rainfall for the $S D-S E$ phase was slightly variable among different sowing dates, and the precipitation only accounted for $11.5 \%$ of the total rainfall over the entire growing period. Both thermal time and growth period in $S E-F L$ phase slightly varied among different sowing dates. Almost $60 \%$ of precipitation happened in $F L-M A$ phase, and D1 had less rainfall compared to other treatments due to the advanced harvest. As for the whole growth period, earlier sowing dates exhibited larger thermal time and potato growth period compared to D5, however, greater precipitation was shown in three intermediate treatments, i.e., D2, D3, and D4.

\subsection{Potato Yield}

Mean values for potato total yield and marketable yield are shown in Table 2. Compared to the last sowing date (between end of May and beginning of June, D5), D3 and D4 significantly increased potato total yield by $18.2 \%$ and $17.7 \%$. D3 and $\mathrm{D} 4$ also showed the highest marketable yields, and the increases compared to D5 were $31.7 \%$ and $26.0 \%$, respectively. As for the ratio of marketable yield 
to total yield, D1 and D5 provided the highest and lowest ratio with the ratio values $73.5 \%, 60.8 \%$, respectively, and the ratios of marketable yield to total yield for D2, D3, and D4 were all about $65 \%$.

Table 2. Mean values of potato total yield (weights in ton/ha), marketable yield (weights in ton/ha), and ratio of marketable yield to total yield (\%) for the different years and sowing dates. The standard deviations for total yield are shown in parenthesis.

\begin{tabular}{|c|c|c|c|c|c|c|}
\hline & Years & D1 & D2 & D3 & D4 & D5 \\
\hline \multirow{5}{*}{ Total yield (ton/ha) } & 2010 & $13.7 \mathrm{~b}(0.5)$ & $16.7 \mathrm{ab}(0.9)$ & 20.9a (1.4) & $21.1 \mathrm{a}(0.6)$ & $20.1 \mathrm{a}(2.3)$ \\
\hline & 2011 & $18.1 \mathrm{a}(2.8)$ & $22.4 \mathrm{a}(0.9)$ & $24.8 \mathrm{a}(2.7)$ & $20.5 \mathrm{a}(1.5)$ & $18.5 \mathrm{a}(1.7)$ \\
\hline & 2012 & $19.6 \mathrm{ab}(0.4)$ & $18.3 \mathrm{~b}(1.0)$ & $19.5 \mathrm{ab}(1.4)$ & $21.9 \mathrm{a}(0.7)$ & $21.1 \mathrm{ab}(1.4)$ \\
\hline & 2013 & $31.6 \mathrm{a}(1.4)$ & $24.4 \mathrm{~b}(1.5)$ & $30.7 \mathrm{a}(1.0)$ & $31.6 \mathrm{a}(1.2)$ & $21.6 \mathrm{~b}(1.0)$ \\
\hline & Mean & 20.8 & 20.7 & 24.0 & 23.9 & 20.3 \\
\hline \multirow{5}{*}{ Marketable yield (ton/ha) } & 2010 & $11.1 \mathrm{~b}$ & $13.4 \mathrm{ab}$ & $15.8 \mathrm{ab}$ & $16.6 a$ & $15.7 \mathrm{ab}$ \\
\hline & 2011 & $13.3 \mathrm{bc}$ & $17.8 \mathrm{ab}$ & $20.4 \mathrm{a}$ & $13.3 b c$ & $11.3 \mathrm{c}$ \\
\hline & 2012 & $13.3 a$ & $8.8 \mathrm{c}$ & $10.6 \mathrm{abc}$ & $10.7 \mathrm{abc}$ & $12.6 \mathrm{ab}$ \\
\hline & 2013 & $19.9 a$ & $14.1 \mathrm{~b}$ & $18.1 \mathrm{ab}$ & $21.3 a$ & $9.6 c$ \\
\hline & Mean & 14.4 & 13.5 & 16.2 & 15.5 & 12.3 \\
\hline \multirow{5}{*}{$\begin{array}{c}\text { Ratio of marketable yield to } \\
\text { total yield }(\%)\end{array}$} & 2010 & 81.04 & 80.67 & 75.14 & 78.53 & 77.70 \\
\hline & 2011 & 80.01 & 79.36 & 82.40 & 65.23 & 61.04 \\
\hline & 2012 & 67.90 & 48.49 & 54.03 & 48.78 & 59.68 \\
\hline & 2013 & 62.65 & 57.94 & 59.29 & 67.66 & 44.92 \\
\hline & Mean & 72.90 & 66.62 & 67.72 & 65.05 & 60.84 \\
\hline
\end{tabular}

Note: Different letters $(\mathrm{a}, \mathrm{b}$ and $\mathrm{c})$ indicate significant differences among the treatments $(p<0.05)$.

\subsection{Water Use Efficiency (WUE)}

WUE for all sowing dates exhibited different changing characteristics among different precipitation years. In drought year (i.e., 2010), delayed sowing dates (D3, D4 and D5) significantly improved WUE compared to D1 and D2 (Figure 4), and D1 showed smallest WUE value. Earlier sowing dates (D1, D2 and D3) promoted WUE compared to D4 and D5 in 2011 (normal year) because of less water consumption, however, these increases for WUE came at the expense of reducing yields. In wet year (i.e., 2013), the WUE values in the D4 and D5 treatments were significantly higher than those in earlier sowing dates.

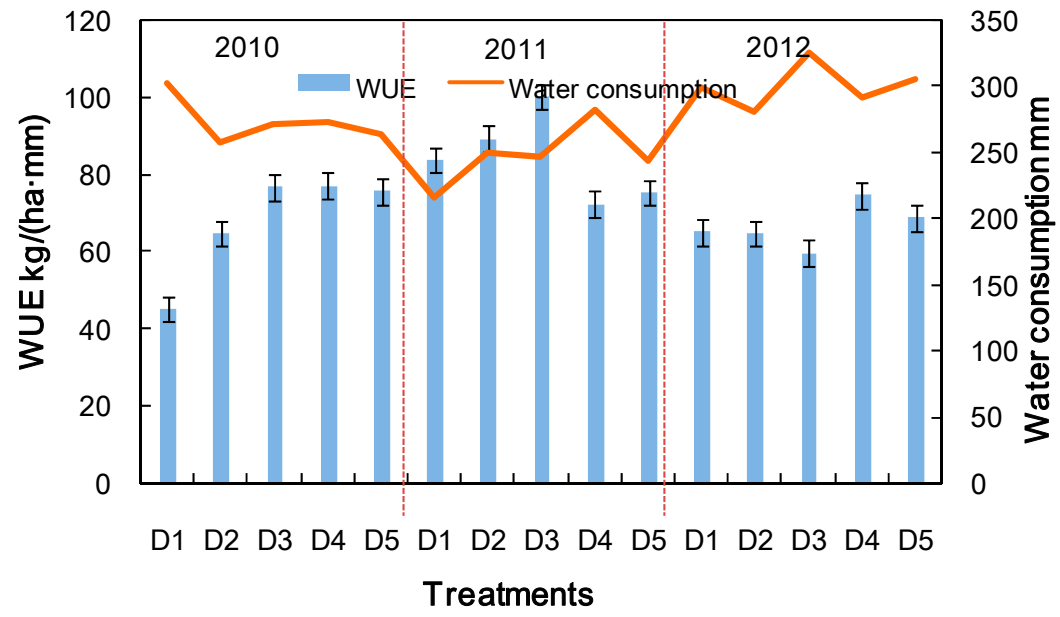

Figure 4. Water use efficiency (WUE) for the different years and sowing dates. Note: Missing soil moisture data for 2013.

\subsection{Leaf Area Index and Dry Mass}

The potato's leaf area index $(L A I)$ showed a high relationship with thermal time after sowing $(\mathrm{R}=0.73, p<0.05)$, as shown in Figure 5a. 


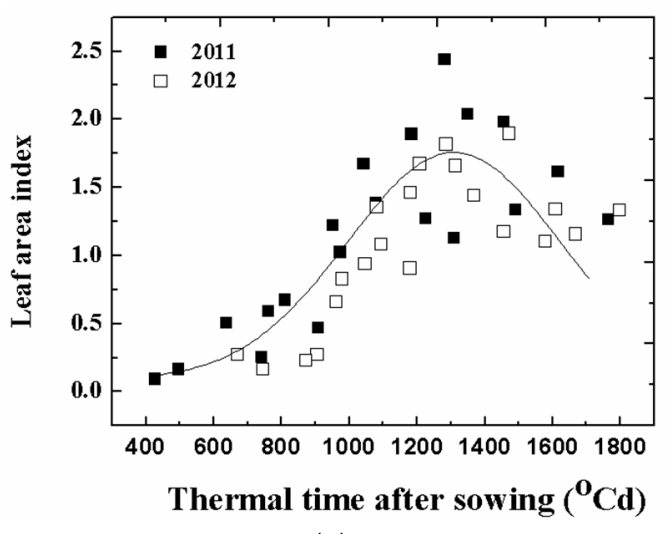

(a)

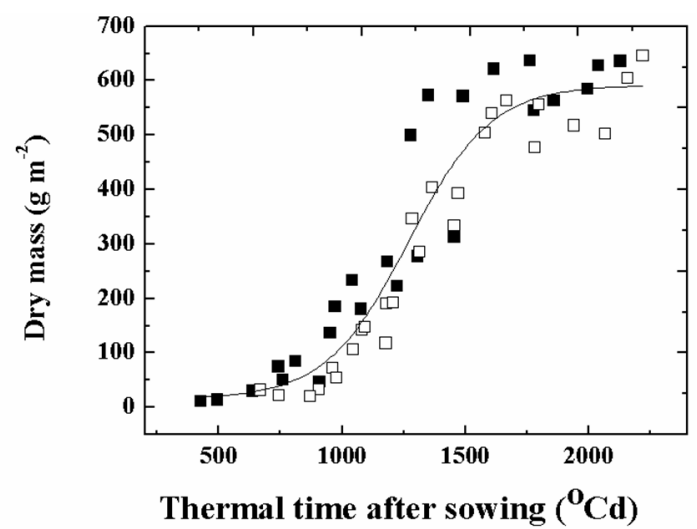

(b)

Figure 5. Relationship between leaf area index $(L A I)$, dry biomass and thermal time after sowing in the year 2011 and 2012. Dry biomass included both above-ground and below-ground biomass. (a) LAI curve exhibited a bell shape and peaked at 2.0 as the thermal time was equal to $1300{ }^{\circ} \mathrm{C}$ day; (b) Dry biomass increased rapidly as the thermal time increased from 900 to $1500{ }^{\circ} \mathrm{C}$ day, and then the curve became flat and stayed stable at about $600 \mathrm{~g} \mathrm{~m}^{-2}$ after the thermal time reached about $1800{ }^{\circ} \mathrm{C}$ day.

The best fitted curve for $L A I$ exhibited a bell shape and peaked at 2.0 as the thermal time was equal to $1300^{\circ} \mathrm{C}$ day. Dry biomass was significantly affected by thermal time after sowing, and a strong positive relationship $(R=0.94, p<0.01)$ was founded between them. Dry biomass increased rapidly as the thermal time increased from 900 to $1500{ }^{\circ} \mathrm{C}$ day (Figure 5b), and then the curve became flat and stayed stable at about $600 \mathrm{~g} \mathrm{~m}^{-2}$ after the thermal time reached about $1800{ }^{\circ} \mathrm{C}$ day. This phenomenon could be explained well by combining the dry biomass and $L A I$ curves: $L A I$ reached the maximum value in the period of $900-1500{ }^{\circ} \mathrm{C}$ day over the entire potato growing season, leading to the highest photosynthesis and rapidly increased biomass, and after this period the biomass slightly increased due to the decreased LAI.

\subsection{Flexible Sowing Date}

According to the daily temperature condition, the elasticity of sowing date can be determined in following steps. First, determine first and last frost dates. In meteorology, frost day is defined as the day with the daily minimum air temperature $<2{ }^{\circ} \mathrm{C}$. Based on the daily minimum temperature data over the period 1960 to 2012 in the study area, first frost date (20 September) and last frost date (5 May) was calculated (Figure 6 Step 1).

Second, determine the last sowing date. Set the first frost date as the starting point, then aggregate sum temperature backward from the starting point until the thermal time reaches the recommended thermal time for potato (Figure $5 \mathrm{~b}$ showed that potato dry biomass stayed stable after about $1800{ }^{\circ} \mathrm{C}$ day, which was considered to be the potato recommended thermal time in this study area), and that point is defined as the last sowing date, i.e., 6 June. Therefore, flexible sowing time was between the last frost date (5 May) and the last sowing date (6 June).

Optimal sowing time, which produced higher potato yield by matching potato critical water stage with peak precipitation, was further calculated. The potato critical water stage showed highest $L A I$ and higher increasing gradient for dry biomass, i.e., the period when the thermal time after sowing was from 900 to $1500{ }^{\circ} \mathrm{C}$ day, as shown in Figure 5 .

Based on the changes in the annual cycle of rainfall from 1960 to 2012 in the study area, the greatest precipitation occurred from 17 July (199th day of year, marked by $R_{\text {First }}$ ) to 6 August (219th day of year, marked by $R_{\text {End }}$ ), as shown in Figure 7 . Setting $R_{\text {End }}$ as the starting point and counting $1500{ }^{\circ} \mathrm{C}$ day thermal time backward from $R_{\text {End }}$, the first optimal sowing date was calculated as 10 May. Similarly, aggregating temperature backward from $R_{\text {First }}$ until the thermal time reaching $900{ }^{\circ} \mathrm{C}$ day, 
the last optimal sowing date was determined as 27 May (see Figure 6). The optimal sowing time for potato in study area, which is the intersection between flexible sowing date and possible optimal sowing dates, was then determined as between 10 May and 27 May.

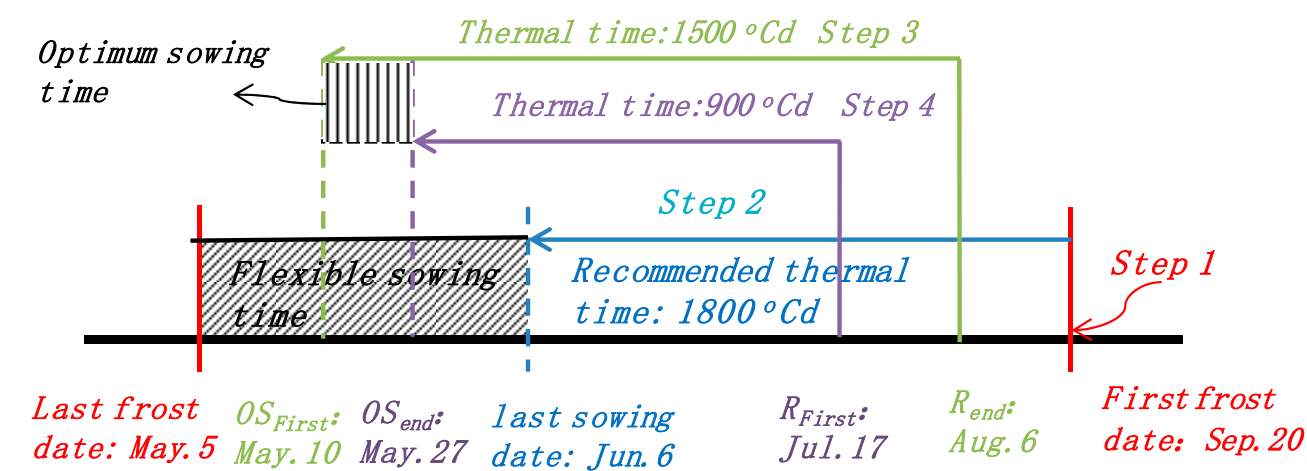

Figure 6. The parameters for determining flexible sowing time and optimum sowing time. Last and first frost dates were 5 May, and 20 September; recommended thermal time was $1800{ }^{\circ} \mathrm{C}$ day; last sowing date was 6 June, and flexible sowing time was 5 May to 6 June. $R_{\text {First }}$ and $R_{\text {End }}$ were 17 July, and 6 August; first and last possible optimum sowing dates were 10 May and 27 May. Optimum sowing time was 10 May to 27 May.

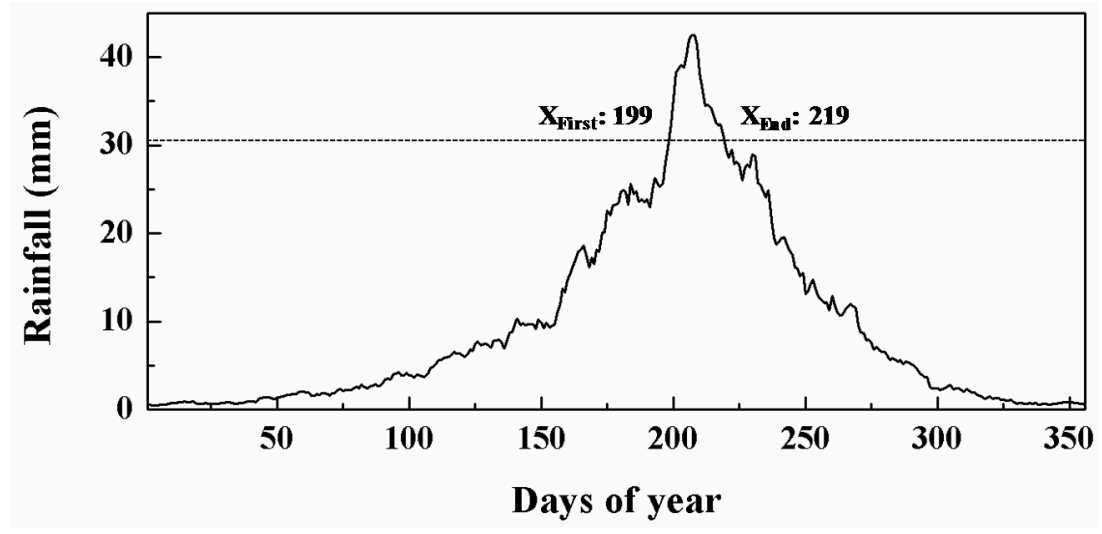

Figure 7. Changes in the annual cycle of rainfall from 1960 to 2012 in study area. Moving average method was used here with 10-day step length.

\section{Discussion}

\subsection{Impact of Sowing Date on Potato Growth, Development and Yield}

Previous studies reported that yields are strongly reduced by a delay of sowing for different crops within a certain sowing range, e.g., sunflower [26,27], soybean [28], and maize [29,30]. Goyne et al. [31] found that crop growth was hastened by a delayed sowing date because the crops encountered higher temperatures during the plant growing period, thus reduce the total dry biomass at harvest. However, the trials carried out in this study showed that D3 and D4 treatments produced both higher potato total and marketable yields compared to the earlier (D1) and later (D5) sowing date. We found that although earlier sowing treatment produced longer growth period and higher thermal time, but it showed greater days and thermal time in $S D-S E$ period, and exhibited non-significant differences in $F L-M A$ period. In addition, precipitation, particularly occurred during the growing season, is the main limiting factor for potato yield besides thermal time, as reported by Song and Hou [32]. The results in this study showed greater precipitation received in three intermediate treatments, i.e., D2, D3, and 
D4; peculiarly, D1 had less rainfall in the $F L-M A$ phase compared to other treatments due to the advanced harvest.

\subsection{Flexible Sowing Time and Optimal Sowing Time}

Since sowing date is one of the most important management factors affecting crop production and quality [33,34], determinations of appropriate sowing dates for various crops in different regions were documented in some previous literatures (e.g., Chen and Chen [35]; Dennett et al. [36]; Olasantan and Bello [37]; Sharma et al. [38]). Most of these studies determined the appropriate sowing dates through analyzing the relationship between the sowing date and yields in the years of trial, so these results might be affected by the environmental conditions (e.g., temperature, rainfall) in the trial years. However, if potato was sown during the flexible sowing period, thermal time may play a non-significant role in controlling potato yield because the difference in the thermal time was small, and the differences in potato yields might only come from the inter-annual variation of precipitation and particularly the precipitation amount during the potato growing season. As reported by Spink [19], the optimal sowing date depended mainly upon the timing of rainfall in a given region, which was beneficial to potato yield by making potato critical water stage matches the period of the precipitation peak. Actually, we also determined the optimal sowing date through taking long-term precipitation and temperature conditions in the study area into account. However, unlike temperature, precipitation showed greater variation between years, so the optimal sowing date might also vary a lot for different years and it only indicated an approximate range of sowing time. We think the optimal sowing date could be determined with an uncertainty of a few days for a given year in the future as the accuracy of precipitation forecast improved. In addition, different cultivars of potato will exhibit different flexible and optimal sowing times, due to the various demands for heat and water during the growth period.

\subsection{Climate Change}

IPCC [39] reported that currently, climate change marked by global warming has occurred over the past 100 years. Hu et al. [40] revealed Inner Mongolia also experienced warming climate, and this could significantly affect potato-sowing date because of the increased thermal time and prolonged frost-free days. Here, we explored the changes of the flexible sowing dates in the study area over the period 1960 to 2012 based on the long-term climate data, as shown in Figure 8.

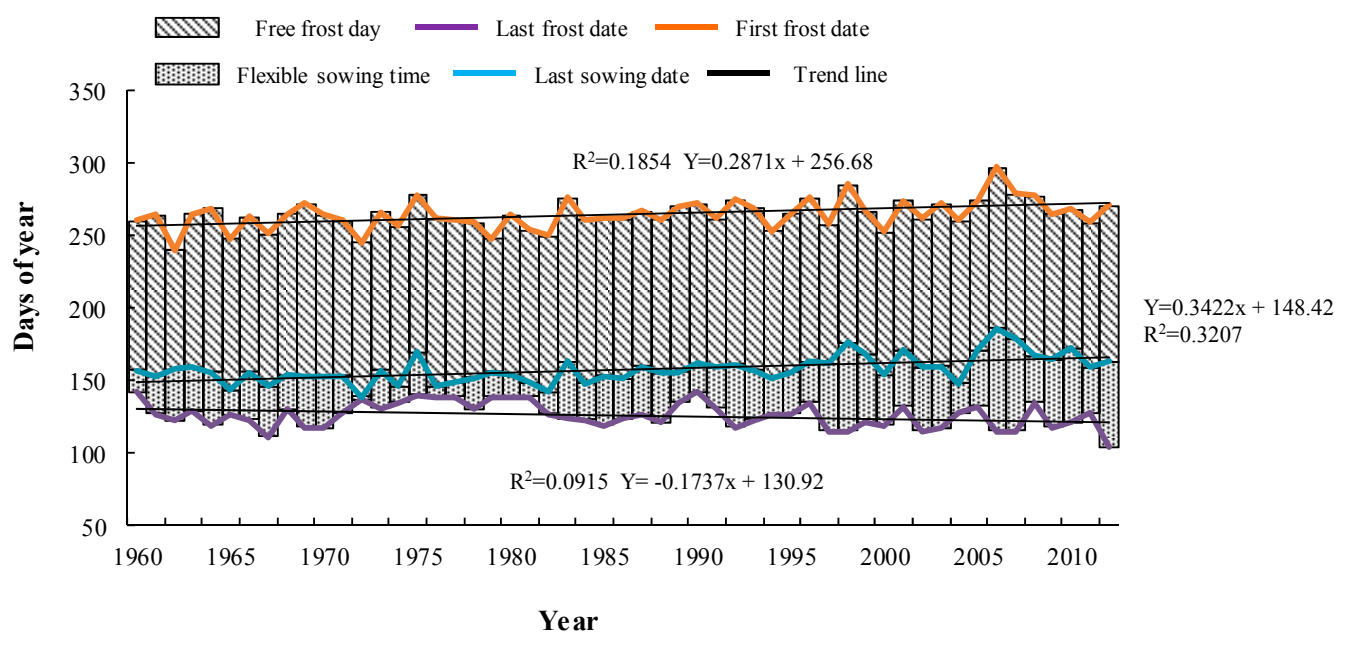

Figure 8. Changes of flexible sowing time, first frost date, and last frost date in study area over the period 1960 to 2012. Trend lines were fitted for last frost date, first frost date, and last sowing date. Results showed the flexible sowing time has increased by 5.1 day/decade due to the advanced last frost date (1.7 day/decade) and delayed last sowing date (3.4 day/decade). 
The flexible sowing dates in the study area had increased by 5.1 day/decade over the past 50 years due to the advanced last frost date (1.7 day/decade) and delayed last sowing date (3.4 day/decade). The delayed last sowing date resulted from two factors: (1) the first frost date was delayed, and potato now could be harvested later than in previous years; (2) increased air temperature determined that the number of days to reach the recommended thermal time for potato growth was less than those in previous years. As for precipitation in potato growing season, an analysis of a long-term time series (over the period 1960 to 2012) of precipitation was also carried out. Results showed that precipitation exhibited great fluctuations among different years, but there was no significant increasing or decreasing trend in the long-term time series of precipitation. Therefore, the temporal variation of the optimal sowing date due to precipitation inter-annual variation was not studied in this paper.

\section{Conclusions}

Sowing date strongly affected potato yield, the delay from an optimum seeding date may cause a yield reduction. Two intermediate sowing dates produced higher potato yields compared to the earlier or later sowing date. In a drier year, delayed sowing dates significantly improved WUE, while higher WUE was found for earlier sowing date in a normal year due to less water consumption. Both the duration and thermal time of potato development period decreased as the sowing date was delayed. However, non-significant thermal time differences in $F L-M A$ period were found among the treatments, because an earlier sowing date showed greater duration and thermal time from sowing to emergence. In addition, intermediate treatments exhibited greater precipitation over the whole growing season, particularly in $F L-M A$ phase. Under the current climate conditions in the study area, the flexible sowing dates for potato were determined as from early May to early June, and optimum sowing time was from 10 May to 27 May. Based on the long-term climate record, the flexible sowing period has been prolonged because of the climate warming.

Acknowledgments: This research was funded by National Basic Research Program of China ('973’ Program: No. 2012CB956204), National Natural Science Foundation of China (No. 41475104, 41271053), and National Science \& Technology Pillar Program during the 12th Five-year Plan Period (No. 2012BAD09B02, 2012BAD20B04). The funding agencies had no involvement in the study design, analysis, interpretation, writing, or publication.

Author Contributions: Xuebiao Pan designed research and provided funding and support; Ning Yang and Xiaoxiao Wang performed research; Pengyu Yang collected the data; Qi hu analyzed the data and wrote the paper; Feifei Pan reviewed and revised the paper. All authors read and approved the final manuscript.

Conflicts of Interest: The authors declare no conflict of interest.

\section{References}

1. Schlosser, C.A.; Houser, P.R. Assessing a Satellite-Era Perspective of the Global Water Cycle. J. Clim. 2007, 20, 1316-1338. [CrossRef]

2. Zhang, B.C. Discussion on basic characteristics and developmental status of rainfall-harvesting technique in arid areas. J. Irrig. Drain. 2008, 27, 119-122.

3. Walther, G.R.; Post, E.; Convey, P.; Menzel, A.; Parmesan, C.; Beebee, T.J.; Fromentin, J.M.; Hoegh-Guldberg, O.; Bairlein, F. Ecological responses to recent climate change. Nature 2002, 416, 389-395. [CrossRef] [PubMed]

4. Wentz, F.J.; Ricciardulli, L.; Hilburn, K.; Mears, C. How much more rain will global warming bring? Science 2007, 317, 233-235. [CrossRef] [PubMed]

5. Qin, D.H.; Ding, Y.H.; Wang, S.W.; Wang, S.M.; Dong, G.R.; Lin, E.D.; Liu, C.Z.; She, Z.X.; Sun, H.N.; Wang, S.R.; et al. Ecological and environmental change in West China and its response strategy. Adv. Earth Sci. 2002, 17, 314-319.

6. Wang, F.X.; Kang, Y.H.; Liu, S.P. Plastic mulching effects on potato under drip irrigation and furrow irrigation. Chin. J. Eco Agric. 2003, 11, 99-102.

7. Lobell, D.B.; Burke, M.B.; Tebaldi, C.; Mastrandrea, M.D.; Falcon, W.P.; Naylor, R.L. Prioritizing climate change adaptation needs for food security in 2030. Science 2008, 319, 607-610. [CrossRef] [PubMed] 
8. Ahmed, S.; Humphreys, E.; Salim, M.; Chauhan, B.S. Optimizing sowing management for short duration dry seeded aman rice on the High Ganges River Floodplain of Bangladesh. Field Crops Res. 2014, 169, 77-88. [CrossRef]

9. Grenz, J.H.; Manschadi, A.M.; Uygur, F.N.; Sauerborn, J. Effects of environment and sowing date on the competition between faba bean (Viciafaba) and the parasitic weed Orobanchecrenata. Field Crops Res. 2005, 93, 300-313. [CrossRef]

10. Kraak, A. Industrial applications of potato starch products. Ind. Crops Prod. 1992, 1, 107-112. [CrossRef]

11. Hou, Q.; Miao, B.L.; Zang, X.W. Study on the forecasting model of potato yield based on drive of climate factors in Yinshan area. Agric. Res. Arid Areas 2012, 30, 247-253.

12. Wu, L.; Shi, X.H.; Yang, H.Y.; Qin, Y.L.; Jia, L.G.; Fan, M.S. Effects of water deficiency at seedling stage on potato yield formation. Chin. Potato J. 2015, 29, 80-84.

13. You, L.; Shen, J.G. Trends of climate change in the past 50 years and the next 10 to 20 years in Inner Mongolia. Meteorol. J. Inner Mong. 2002, 4, 14-18.

14. He, F.; Wang, K.; Li, X.L.; Xu, Z. Effects of ridge and furrow rainfall harvesting system of on soil hydrothermal condition and yields of Elymus sibiricus L. in arid and semiarid regions. Trans. CSAE 2012, 28, 122-126.

15. Tavakkoli, A.R.; Oweis, T.Y. The role of supplemental irrigation and nitrogen in producing bread wheat in the highlands of Iran. Agric. Water Manag. 2004, 65, 225-236. [CrossRef]

16. Bange, M.P.; Hammer, G.L.; Rickert, K.G. Environmental control of potential yield of sunflower in the subtropics. Aust. J. Agric. Res. 1997, 48, 231-240. [CrossRef]

17. Bassu, S.; Asseng, S.; Motzo, R.; Giunta, F. Optimising sowing date of durum wheat in a variable Mediterranean environment. Field Crops Res. 2009, 111, 109-118. [CrossRef]

18. Turner, N.C. Agronomic options for improving rainfall-use efficiency of crops in dryland farming systems. J. Exp. Bot. 2004, 55, 2413-2425. [CrossRef] [PubMed]

19. Spink, J.H.; Semere, T.; Sparkes, D.L.; Whaley, J.M.; Foulkes, M.J.; Clare, R.W.; Scott, R.K. Effect of sowing date on the optimum plant density of winter wheat. Ann. Appl. Biol. 2000, 137, 179-188. [CrossRef]

20. Yang, N.; Pan, X.B.; Zhang, L.Z.; Wang, J.; Dong, W.L.; Hu, Q.; Li, Q.Y.; Wang, X.X.; Tang, J.Z.; Liu, Z.; et al. Optimal sowing dates improving yield, water and nitrogen use efficiencies of spring wheat in agriculture and pasture ecotone. Trans. Chin. Soc. Agric. Eng. 2014, 30, 87-90.

21. Conry, M.J. Influence of seed rate and sowing date on the yield and the grain quality of Blenheim spring malting barley in the south-east of Ireland. J. Agric. Sci. Camb. 1998, 130, 307-315. [CrossRef]

22. Cirilo, A.G.; Andrade, F.H. Sowing date and kernel weight in maize. Crop Sci. 1996, 36, 325-331. [CrossRef]

23. Otegui, M.E.; Nicolini, M.G.; Ruiz, R.A.; Dodds, P.A. Sowing date effects on grain yield components for different maize genotypes. Agron. J. 1995, 87, 29-33. [CrossRef]

24. Barros, J.F.; de Carvalho, M.; Basch, G. Response of sunflower (Helianthus annuus L.) to sowing date and plant density under Mediterranean conditions. Eur. J. Agron. 2004, 21, 347-356. [CrossRef]

25. Hu, Q.; Pan, F.F.; Pan, X.B.; Zhang, D.; Yang, N.; Pan, Z.H.; Zhao, P.Y.; Tuo, D.B. Effects of a ridge-furrow micro-field rainwater-harvesting system on potato yield in a semi-arid region. Field Crops Res. 2014, 166, 92-101. [CrossRef]

26. De la Vega, A.J.; Hall, A.J. Effects of planting date, genotype, and their interactions on sunflower yield. I. Determinants of oil-corrected grain yield. Crop Sci. 2002, 42, 1191-1201. [CrossRef]

27. De la Vega, A.J.; Hall, A.J. Effects of planting date, genotype, and their interactions on sunflower yield. II. Components of oil yield. Crop Sci. 2002, 42, 1202-1210. [CrossRef]

28. Andrade, F.H. Analysis of growth and yield of maize, sunflower and soybean grown at Balcarce, Argentina. Field Crops Res. 1995, 41, 1-12. [CrossRef]

29. Cirilo, A.G.; Andrade, F.H. Sowing date and maize productivity: I. Crop growth and dry matter partitioning. Crop Sci. 1994, 34, 1039-1043. [CrossRef]

30. Cirilo, A.G.; Andrade, F.H. Sowing date and maize productivity: II. Kernel number determination. Crop Sci. 1994, 34, 1044-1046. [CrossRef]

31. Goyne, P.J.; Schneiter, A.A.; Cleary, K.C.; Creelman, R.A.; Stegmeier, W.D.; Wooding, F.J. Sunflower genotype response to photoperiod and temperature in field environments. Agron. J. 1989, 81, 826-831. [CrossRef]

32. Song, X.F.; Hou, Q. Influence of climate conditions on potato yield. Chin. J. Agrometeorol. 2003, 24, 35-38.

33. McLeod, J.G.; Campbell, C.A.; Dyck, F.B.; Vera, C.L. Optimum seeding date for winter wheat in southwestern Saskatchewan. Agron. J. 1992, 84, 86-90. [CrossRef] 
34. Ferrise, R.; Triossi, A.; Stratonovitch, P.; Bindi, M.; Martre, P. Sowing date and nitrogen fertilisation effects on dry matter and nitrogen dynamics for durum wheat: An experimental and simulation study. Field Crops Res. 2010, 117, 245-257. [CrossRef]

35. Chen, L.D.; Chen, G.B. Study on Climatic Bases Increasing Potato Yield for No-tillage Cultivation with Straw Covering and Optimum Sowing Date in Winter of Yuling City. J. Meteorol. Res. Appl. 2008, 1, 017.

36. Dennett, M.D.; Satorre, E.H.; Slafer, G.A. Effects of sowing date and the determination of optimum sowing date. Wheat Ecol. Physiol. Yield Determ. 1999, 5, 123-140.

37. Olasantan, F.O.; Bello, N.J. Optimum sowing dates for okra (Abelmoschusesculentus) in monoculture and mixture with cassava (Manihotesculenta) during the rainy season in the south-west of Nigeria. J. Agric. Sci. 2004, 142, 49-58. [CrossRef]

38. Sharma, D.L.; D'Antuono, M.F.; Anderson, W.K.; Shackley, B.J.; Zaicou-Kunesch, C.M.; Amjad, M. Variability of optimum sowing time for wheat yield in Western Australia. Crop Pasture Sci. 2008, 59, 958-970. [CrossRef]

39. Intergovernmental Panel on Climate Change (IPCC). Intergovernmental Panel on Climate Change; IPCC: Geneva, Switzerland, 2014.

40. Hu, Q.; Pan, F.F.; Pan, X.B.; Zhang, D.; Li, Q.Y.; Pan, Z.H.; Wei, Y.R. Spatial analysis of climate change in Inner Mongolia during 1961-2012, China. Appl. Geogr. 2015, 60, 254-260. [CrossRef]

(C) 2017 by the authors. Licensee MDPI, Basel, Switzerland. This article is an open access article distributed under the terms and conditions of the Creative Commons Attribution (CC BY) license (http:/ / creativecommons.org/licenses/by/4.0/). 